\title{
Corporate culture: The perceptions of personnel managers in South Africa
}

\author{
J. Viljoen* \\ Department of Business Administration, Rhodes University, Grahamstown, 6140 Republic of South Africa
}

Received 13 July 1987; accepted 18 August 1987

\begin{abstract}
In this paper some core domensions along which corporate culture can be analysed are identified. It is argued that, for large scale studies of corporate culture, personnel managers are the most appropriate sampling base. Using a mailed questionnaire a sample of 199 South African companies was surveyed in order to isolate their cultural attributes as perceived by the personnel manager. The research findings revealed: (i) a strong association between strategic management style and perceived culture strength; (ii) greater perceived performance potential and better labour relations amongst strong culture companies, and (iii) significant differences in perceived culture strength between managerial and non-managerial employees. The implications of these findings are discussed.
\end{abstract}

In hierdie artikel word sekere basiese eienskappe geïdentifiseer waardeur die korporatiewe kultuur geanaliseer kan word. Vir grootskaalse studies van eenheidskultuur is personeelbestuurders waarskynlik die mees toepaslike steekproef. 'n Steekproef van 199 maatskappye is per pos genader om eienskappe van hul kultuur soos gesien deur die personeelbestuurder, te identifiseer. Die navorsing het die volgende aan die lig gebring: (i) 'n sterk verband tussen strategiese bestuurswyse en waarneembare kultuursterkte; (ii) groter waarneembare prestasiepotensiaal en beter arbeidsbetrekkinge onder maatskappye met sterk kulture; en (iii) betekenisvolle verskille in kultuursterktes tussen bestuur en werknemers. Die implikasies van hierdie resultate word bespreek.

* Present address: School of Management, Deakin University, Victoria, 3217 Australia

\section{Introduction}

Since the 1970s the increasing volatility of the corporate environment has spawned some dramatic changes in the philosophy and practice of management. In the past South African organizations could base their operations on the assumptions of a docile competitive environment, predictable government, slowly evolving technologies and a tolerant society. As a result, organizations were internally stable and well ordered. Job patterns and responsibilities were clear and top-down authority relationships predominated as 'scientific' managers planned, motivated, organized and controlled the unskilled and repetitive activities of the workers beneath them. Management based its actions on a totalitarian, rather than a democratic view of man (Sullivan, 1986).

The phenomenon of 'scientific' management has been brought into question in South Africa, as elsewhere in the world, by the evolution of an educated, questioning society concerned with human dignity and searching to interact on the basis of mutual respect and voluntary cooperation rather than submission and self-sacrifice. The reduced stability and predictability in all elements of the human environment (particularily technology) combined with a higher level of expectations, a greater emphasis on human rights and a desire for bottom-up participation in society has made the traditional 'scientific' approach to management seem rather sterile and inappropriate (Kanter, 1983). Not only must managers now devote more attention to aligning their business with projected external developments, they also have to come to terms with employees born of a more liberated and demanding society (Pinchot, 1985). A primary means of facilitating corporate success under these conditions is the development and maintenance of an appropriate, supportive organizational culture (Barney, 1986; Deal \& Kennedy, 1982; Peters \& Austin, 1985; Peters \& Waterman, 1982).

\section{The nature and significance of corporate culture}

Culture may be defined as the philosophy, attitudes, beliefs and shared values upon which the organization operates and which determine the problem-solving behaviour of all its employees. Every organization has a unique integrated system of acquired behavioural patterns which influences its entire modus operandi (King \& Clelland, 1978). Like societal cultures, organizational cultures are learned, predominantly through experience, over long periods of time. They reflect the combined wisdom of the organization in its attempt to integrate its internal operations so as to optimize its ability to adapt to a changing external environment (Schein, 1984). Many authorities believe that a strong culture is the key to organizational performance (eg. Deal \& Kennedy, 1982; Pascale, 1985; Peters \& Waterman, 1982; Pettigrew, 1979; Schein, 1984). This belief is derived from the observation that strong culture organizations are expert at implementing strategic plans. They seem to understand what needs to be done in order to achieve an objective and are strongly motivated to take the appropriate action. This is in direct contrast with weak culture organizations which may be expert at developing and perfecting strategic plans but which find that somehow the expected results seldom materialize. Weak cultures are characterized by a lack of awareness and interest in the goals of the organization. Here strategies are implemented through extrinsically imposed methods, procedures, policies and operational guidelines in order to direct and control the activities of 
employees. While this externally imposed strategic guidance system can effectively operate in small organizations it soon reaches its capacity to influence behaviour (Ouchi, 1982). Directives are misinterpreted and cannot be effectively controlled as they filter down through large organizations. Furthermore, the sheer volume of directives, controls and monitoring systems necessary to run the organization in this way, leads to a conservative and unresponsive bureaucracy.

Strong culture organizations, on the other hand, display motivated and unified goal-orientated behaviour which appears to provide employees with an intrinsic guidance system and prevents bureaucratic malaise. It may well be that the success of strong culture organizations is their ability to provide stable affiliations for employees. Ouchi (1982) maintains that rapid social change, urbanization and high degrees of geographic mobility have resulted in a breakdown of the traditional sources of affiliation - family, church, neighbourhood and voluntary association. These unfulfilled affiliation needs are being partially satisfied by strong culture organizations because these organizations represent meaningful human institutions rather than a necessary daily evil to be endured for the sake of maintaining a desired standard of living. It may be argued that the generally poor social conditions facing the average black employee in South Africa, enhances the potential for organizations to create the kind of working environment which can serve as a source of affiliation.

\section{Some central dimensions of corporate culture}

In order to analyse culture within organizations it is first necessary to identify the components, or dimensions, of culture. Once these have been isolated it is possible to determine their impact on culture strength.

It is common practice, when analysing culture, to begin by constructing a list of phrases describing the informal rules which govern behaviour in the organization. Changes in strategy are then analysed in terms of these informal rules (Deal \& Kennedy, 1982). Employees from different hierarchical levels and functional areas make subjective generalizations about the ability of the culture to accommodate the proposed new strategy. While participants may gain a greater understanding of the human element of the organization, this approach usually results in confusion because culture is not analysed in terms of specific elements of organizational activity. In order to overcome this deficiency, it is possible for the culture analyst to identify key organizational activities which both determine and reflect organizational culture. These are the basic elements of culture and they provide a convenient framework within which culture can be meaningfully investigated.

\section{The organization's critical success factors}

Every organization is faced with a different reality in the marketplace depending on its own unique products, customers, competitors, internal capabilities, technological expertise, and so on. In analysing these variables and their likely future trends, each company should be able to isolate at least one performanee criterion which it must carry out well - in fact which may be critical to the success of the organization (Ohmae, 1982). This is commonly termed the 'critical success factor' and is probably the single greatest influence on corporate culture. For example, some computer manufacturers see technological innovation as being critical to their long-run success, while some focus on customer service and others on the specialized application of computer technology. Some feel that a combination of all of these factors is most appropriate. Whatever the case may be, each company - depending on its selected critical success factor - is now free to mould the entire spectrum of its operations to bring them into line with that critical success factor. This ensures that every person in the organization is aware of the real priorities of the company and is able to see his job activities in terms of these priorities (Morse \& Martin, 1983). In this way a cost leadership critical success factor for example, will translate directly into productivity, decision support system and technology goals as well as bulk purchasing and mass marketing distribution plans. As a result, employees will understand exactly how the critical success factor is to be operationalized.

\section{The values of the organization}

The values of an organization should be directly derived from its critical success factors and constitute the basic philosophy and beliefs which guide the activities and decisions of employees (Deal \& Kennedy, 1982). For example, a company which believes that innovation is the key to success in its industry may adopt the value of 'product innovation and creativity'. Accordingly, it will develop a range of support mechanisms to ensure that these values are enacted:

- It may insist that a certain percentage of its profit from each division be derived from products less than five years old.

- It may pursue a policy of drastic decentralization pushing authority and decision making as far down the organization as possible in order to encourage many new ideas and approaches.

- It may adjust many of its methods and processes such as selection and recruitment, induction, training, performance appraisal and reward systems, in order to reinforce the new value system.

All organizations have a value system, though in many cases it is not formalized but is indirectly learned by employees through watching the actions of successful others in the company. If divergent and incompatible values are allowed to evolve in an organization, conflict will inevitably result as employees apply different rules and act according to their different value systems. Hence a major managerial task is to attempt to develop value consistency within their organizations.

Many of the values of an organization are explicit within its plans, policies and operating procedures. Other values are not explicitly stated. These values are 
held at a subconscious level and only manifest themselves through the observed consistent behavioural patterns of employees. That is, employees are unaware of any objective reason for doing things the way they do, they behave in a certain way because 'that's the way things are done in this organisation'. All new employees should be socialized into the organization to ensure that they hold the pivotal values of the culture (Pascale, 1985). Likewise, in high-performing companies, a rigid application of promotion from within should be followed to reaffirm the company's faith in its employees and to maintain value strength (Townsend, 1984).

\section{The style of management predominating within the} organization

Management style refers to the approach that managers adopt to their tasks and reflects their collective philosophy about the priorities of the business. Although management style can be classified in several different ways (Brodwin \& Bourgeois, 1984) there are three broad categories of relevance when analysing corporate culture:

- Autocratic management embodies the philosophy that there is a clear distinction between the 'thinkers' (top management) and 'doers' (all other employees) in an organization. Strategies are devised by senior management who present these to the rest of the organization as a fait accompli, demand their implementation and monitor progress by using an elaborate system of controls.

- Collaborative management is based on the principle that the quality of corporate decisions will be improved by including more 'knowledgable' employees (down to the lower/middle management categories) in the decision-making process. This common style is characterized by management committees, business teams and weekends at secluded resorts working out the next 'best strategy' for the company.

- Participative management, as the name implies, embodies the philosophy that strategies should be developed both from the top down and from the bottom up. All employees, including those at the lowest levels, are encouraged to produce ideas and these ideas are actively supported if they contain some merit. All employees are made aware of the mission of the business and the basic philosophy and values this mission implies. In this way input to the decisionmaking process by all employees is kept relevant and focused. Bureaucracy is avoided by establishing many decentralized divisions, each having a major input into its own planning and control functions and there is effective communication between hierarchical levels. However, as Viljoen (1986) points out, participation must take place within a climate of honesty, trust and respect for the individual or else it will be seen as little more than a gimmick by employees.

The general movement away from 'scientific' management implies a greater degree of employee participation. However, within this general trend it is still clear that different strategies (and their associated critical success factors) will require different styles of management. For example, a strategy of 'leadership in innovation' generally requires a greater degree of decentralized, bottom-up (participative) management, whilst a strategy of 'cost leadership' requires more topdown management autocratic management by specialists in engineering, systems design and production control. An organization should not be permeated by a particular style of management which persists over several decades despite the fact that its primary strategy may have altered significantly during this period.

\section{Key organizational practices}

Apart from the above-mentioned specific dimensions of culture, the literature is consistent regarding some basic organizational practices which appear to enhance culture strength. Among the more common of these is the premise that every employee has a useful contribution to make, is not afraid of responsibility, and is an important source of innovative ideas. Accordingly, it is important that employees have a holistic view of the organization and be kept fully informed on a broad range of organizational matters - well beyond those limited to the requirements of the job. The ability of management to bring the best out of employees is also important. This requires managers to possess effective behavioural skills rather than purely technical skills. Furthermore, group interaction predominates and teamwork appears important in strong culture companies. There is also a need to balance the strict controls necessary for corporate discipline with the flexibility businesses need in order to respond timeously to changes in the environment (Goldsmith \& Clutterbuck, 1984). Many controls appear to be most effective when practised through concensus rather than through dictate. Finally, in accordance with basic strategic management principles, it is important that a long-run mentality pervades the organization. In particular, employee performance and evaluation should not be rigidly linked to short-term measurement criteria.

\section{Personnel management and corporate culture}

The personnel function in the organization is essentially concerned with the design, implementation, evaluation and administration of human resource programs. As such this function has a potentially significant effect on the culture of any given organization. This effect could occur through any of the dimensions of culture as Figure 1 illustrates.

The perceptions of personnel management regarding the critical success factors, values and management style of the organization, will have a strong influence over the entire spectrum of personnel management activities. Similarly, many organizational practices pertinent to the development of a specific corporate culture are initiated and implemented (or at least tacitly condoned) by the personnel management function. In total, personnel managers have an important role to play in the 


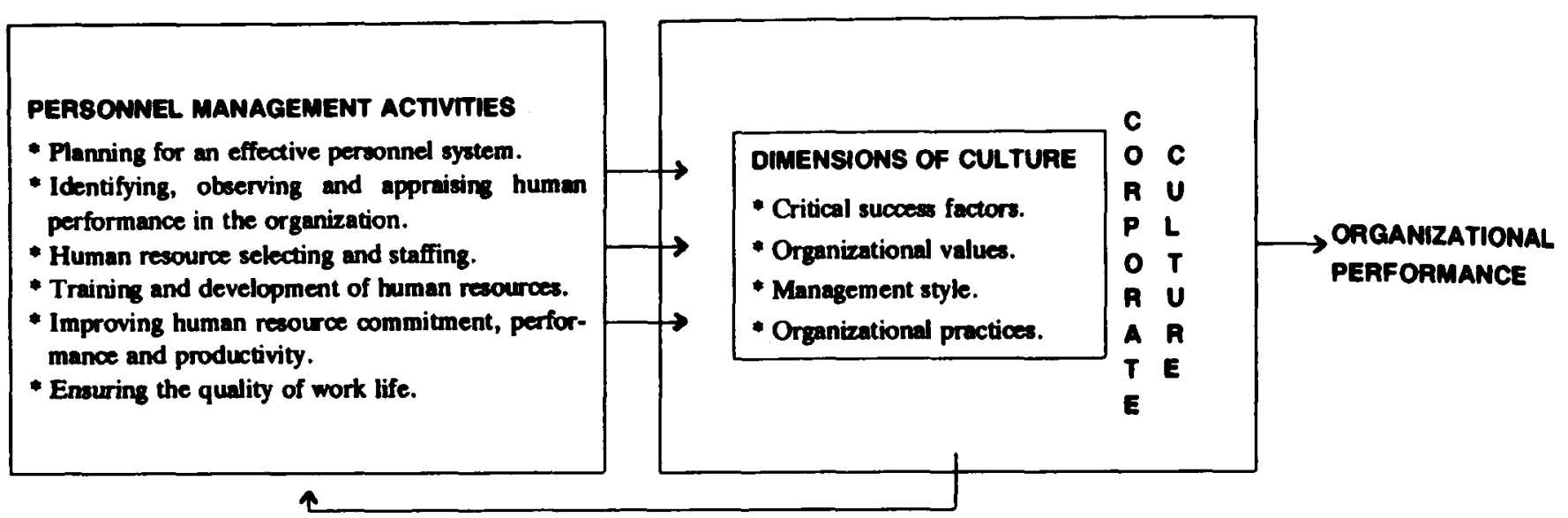

Figure 1 The impact of personnel management on corporate culture

development, maintenance or change of an organization's culture. Furthermore, as persons trained specifically in the field of human resources, personnel managers are probably more able than any other of their management colleagues to understand and analyse the culture of their respective organizations. This fact, together with their potentially significant impact on corporate culture, makes personnel managers an attractive and appropriate sampling case for large scale culture studies where direct sampling of many individual employees in large numbers of different organizations is impractical.

In order to investigate the cultural attributes (as perceived by personnel managers) of a sample of South African companies using the concepts and dimensions referred to thus far, an appropriate methodology was developed, as detailed in the following section.

\section{Research objectives and Methodology}

Questionnaires were mailed to the personnel managers of $\mathbf{4 8 0}$ randomly selected members of the Chambers of Commerce and Industry of the Eastern Province and Border. A total of 199 responses was received representing a response rate of $41,5 \%$.

In order to ensure that reliable information was received from respondents, the concepts of corporate culture, strategic planning and primary strategic value (critical success factor) were fully explained in the covering letter which accompanied the questionnaire and in the relevant sections of the questionnaire itself.

Respondents were categorized according to the following variables:

1. Company size $(0-49,50-99,100-199,200-499$, 500 and over employees).

2. Economic sector (manufacturing/construction, retail/ wholesale, service).

3. Primary strategic value (quality, customer service, low cost/efficiency, specialization/focus).

4. Strategic management style (autocratic, collaborative, participative, no strategic management).

Furthermore, each respondent company was tested for three separate measures of culture strength as perceived by the personnel manager:
Strength of management culture: This item was measured using the composite score attained for five Likert-type interval scale questions. (See Appendix 1).

Culture strength amongst non-management staff: This item was measured using the same questions and scales as used for management. (See Appendix 1).

Overall strength of corporate culture: This item was measured using the composite score attained on twelve Likert-type interval scale questions. (The question format and composition of this measure is given in Appendix 2).

The overall objective of this research was to isolate and investigate those characteristics of companies which are associated with different cultural attributes. Three specific research objectives were formulated:

1. To ascertain which of the following variables can be used to explain variations in perceived culture strength:

- Company size, measured in terms of employee numbers?

- Economic sector in which the respondent company competes?

- Primary strategic value of the company?

- Strategic management style of the company?

The chi square test was used as the primary measure of association by cross-tabulating each of the independent variables with perceived culture strength (the dependent variable).

2. To measure any association between perceived culture strength and self-rated organizational performance (measured in terms of future competitive potential and comparative state of labour relations).

3. To ascertain whether personnel managers perceived cultural unity or cultural diversity within their respective organizations. This was accomplished through the use of questions requiring a separate response for managerial and non-managerial staff. A range of five questions (each measuring a separate element of culture strength) was used. The students $t$ test was employed to test for significant difference between the response items. 


\section{Research findings Culture strength}

Using the chi square test no significant association was found between perceived culture strength and the variables company size, economic sector and primary strategic value. However, perceived culture strength was strongly associated with strategic management style (see Table 1). This would indicate, as expected in terms of culture theory, that culture strength is independent of variations in demographic type organizational variables. That is, according to this study, strong (or weak) cultures can exist equally successfully in large or small organizations, in organizations which compete in totally different economic sectors, and in organizations with totally different strategic orientations.

In the survey questionnaire strategic management

Table 1 Association between culture strength and selected research variables

\begin{tabular}{lcc}
\hline Research variable & $\begin{array}{c}\text { Level of association with } \\
\text { culture strength (chi square) }\end{array}$ & Significance \\
\hline $\begin{array}{l}\text { 1. Company size } \\
\begin{array}{l}\text { 2. Economic sector of } \\
\text { respondent company }\end{array}\end{array}$ & 6,11 & None \\
$\begin{array}{l}\text { 3. Primary strategic value } \\
\text { 4. Strategic management }\end{array}$ & 3,88 & None \\
style & 3,38 & None \\
\hline
\end{tabular}

style was tested in four categories: 'autocratic', 'collaborative', 'participative', and 'no formal strategic planning conducted'. The research findings show a clear perceived preference for autocratic management styles within the respondent companies (see Table 2).

Strategic management style was then subjected to an analysis of variance (ANOVA) test to find if a significant difference existed between the mean culture scores for

Table 2 Strategic management style in respondent companies

Long-term strategic planning

in your company is:

Performed predominantly by top man-

agement and communicated to the rest of [Autocratic] $n=92(46 \%)$

the organization once the plan has been

finalised.

Performed by all levels of management as

a working group and subsequently com- [Collaborative] $n=66(33 \%)$

municated to the rest of the organization.

Performed by all levels of management

together with substantial input from [Participative] $n=24(12 \%)$

working groups of non-managerial

employees.

There is no formal strategic planning [None] $n=18 \quad(9 \%)$

performed in this company
Table 3 Mean culture scores measured by strategic management style category (ANOVA)

\begin{tabular}{lccccc}
\hline $\begin{array}{l}\text { Strategic } \\
\text { management } \\
\text { category }\end{array}$ & $n$ & $\begin{array}{c}\text { Mean culture } \\
\text { score } \\
\text { (Scale: } 1-5)\end{array}$ & $S D$ & $F$ ratio & $F$ prob. \\
\hline Autocratic & 92 & 3,45 & 0,64 & & \\
Collaborative & 66 & 3,67 & 0,58 & 9,08 & 0,001 \\
Participative & 24 & 2,87 & 0,50 & & \\
None & 18 & 2,90 & 0,86 & & \\
\hline
\end{tabular}

each category. The results of the ANOVA are given in Table 3.

The findings indicate that different strategic management styles are associated with different levels of culture strength, the rank order being; participative collaborative - autocratic, with those companies which conduct no formal strategic planning scoring lowest. In separate ANOVA tests this rank order of categories was reflected in ten of the twelve individual items which in aggregate comprised the total culture strength score for each company. Hence two items in the questionnaire can be isolated in this study as not being reliable measures of culture strength. These items have been indicated in Appendix 2.

\section{Culture strength and organizational performance}

In order to determine whether culture strength could be associated with improved organizational performance, personnel managers were requested to assess:

- Their organization's performance potential in comparison with competitors, and

- The perceived state of labour relations within their respective companies in comparison with competitors.

A three-point self-rating scale was used; worse than competitors, on a par with competitors, better than competitors. The culture scores for these three categories were tested for variance and the results are given in Table 4.

Given the limitations of self-rating scales with respect to performance items, the findings show a more positive perception of future potential and a more favourable perceived state of labour relations amongst companies with stronger cultures (as rated by personnel managers).

\section{Cultural duality}

In terms of the third research objective, five questions requiring separate responses on behalf of managerial and non-managerial staff were included in the questionnaire in order to test for perceived cultural duality in respondent companies (see Appendix 1). In individual tests each question resulted in a significantly different mean culture score for managerial and nonmanagerial employees. The five items were then aggregated to create a composite culture score for each category of employee which was again tested for means difference. The findings are given in Table 5.

Table 5 indicates a strong case of perceived cultural 
Table 4 Performance potential, labour relations and culture strength in respondent companies

\begin{tabular}{|c|c|c|c|c|}
\hline \multirow[b]{2}{*}{$\begin{array}{l}\text { Performance } \\
\text { category }\end{array}$} & \multicolumn{4}{|c|}{ Mean culture ANOVA } \\
\hline & $n$ & $\begin{array}{c}\text { Score } \\
\text { (Scale 1-5) }\end{array}$ & $\begin{array}{c}f \\
\text { statistic }\end{array}$ & $F$ prob. \\
\hline Future competitive potential & & & & \\
\hline a) Better than competitors & 96 & 3,65 & & \\
\hline b) Worse than or on par & & & 9,02 & 0,005 \\
\hline with competitors & 99 & 3,37 & & \\
\hline $\begin{array}{l}\text { Perceived state of labour } \\
\text { relations }\end{array}$ & & & & \\
\hline a) Better than competitors & 107 & 3,62 & & \\
\hline $\begin{array}{l}\text { b) Worse than or on par with } \\
\text { competitors }\end{array}$ & 89 & 3,37 & 6,97 & 0,009 \\
\hline
\end{tabular}

Table 5 Cultural duality in respondent companies

\begin{tabular}{|c|c|c|c|c|c|}
\hline Item number* & $n$ & $\begin{array}{l}\text { Mean culture } \\
\text { score } \\
\text { (scale 1-5) }\end{array}$ & $S D$ & $\begin{array}{l}t \text { test } \\
\text { value }\end{array}$ & $\begin{array}{l}\mathrm{b} \\
\text { sig. of } t\end{array}$ \\
\hline 1. Management & 193 & 3,44 & 1,51 & 4,92 & 001 \\
\hline Non-management & & 2,92 & 1,50 & & \\
\hline 2. Management & 188 & 3,21 & 1,49 & 5,97 & 001 \\
\hline Non-management & & 2,87 & 1,49 & & \\
\hline $\begin{array}{l}\text { 3. Management } \\
\text { Non-management }\end{array}$ & 188 & $\begin{array}{l}4,25 \\
3,76\end{array}$ & $\begin{array}{l}1,01 \\
1,24\end{array}$ & 8,41 & 001 \\
\hline $\begin{array}{l}\text { 4. Management } \\
\text { Non-management }\end{array}$ & 188 & $\begin{array}{l}4,61 \\
3,80\end{array}$ & $\begin{array}{l}0,73 \\
1,16\end{array}$ & 10,76 & 001 \\
\hline $\begin{array}{l}\text { 5. Management } \\
\text { Non-management }\end{array}$ & 185 & $\begin{array}{l}4,14 \\
3,20\end{array}$ & $\begin{array}{l}0,97 \\
1,17\end{array}$ & 11,25 & 001 \\
\hline 6. (Composite score) & & & & & \\
\hline $\begin{array}{l}\text { Management } \\
\text { Non-management }\end{array}$ & 196 & $\begin{array}{l}3,91 \\
3,28\end{array}$ & $\begin{array}{l}0,74 \\
0,87\end{array}$ & 14,36 & 001 \\
\hline
\end{tabular}

duality in respondent companies. On Likert interval scales of one to five the culture strength index, as scored by the personnel manager, was consistently higher amongst managerial staff than amongst non-managerial employees.

\section{Discussion}

This paper argues that personnel managers are a reliable and appropriate source of information pertaining to the corporate culture of their respective organizations. In the first instance, because of their particular skills and qualifications within the area of human resources management, the opinions and perceptions of personnel managers should be strongly indicative of organizational reality concerning issues of culture. Furthermore, through the whole gamut of personnel management activities (see Figure 1), personnel managers have a significant impact on the organization's human resource system and therefore play an important role in shaping the future culture of the organization.

Using personnel managers as respondents this research survey supports the notion that culture strength and strategic management style are strongly related. There is clear evidence that various strategic management styles are associated with different levels of culture strength. Participative management is associated with the strongest cultures followed by collaborative management and autocratic management. Those companies which practice no formal strategic management are strongly associated with weak corporate cultures. There is also evidence to suggest that in comparison with competitors, the personnel managers of companies with stronger cultures have a more positive perception of both their future performance potential and their current labour relations. This finding argues in favour of a more widespread acceptance of participative management styles in South African companies. Whilst participative management is clearly associated with stronger cultures, it was the least popular of the formal styles of management amongst respondent companies. This finding is possibly a reflection of lack of faith in the abilities of lower level workers as a result of the generally low education and skill characteristics of these employees. Clearly, the desire to centralize control at the top of the organization has led to a strong preference for autocratic management styles in the research sample. However, the research shows that these companies bear the opportunity cost of relatively weak corporate cultures. In an attempt to gain some of the benefits of participation without losing control, collaborative management was practiced by $33 \%$ of the research sample.

Support for the principle that cultural traits should permeate the entire organization both laterally and vertically, was not found in the research sample. Personnel managers perceive strong differentiation between culture strength in managerial and nonmanagerial staff. Such cultural duality is consistent with the predominance of autocratic management in the sample and is also a reflection of the racial composition of the work-force. Furthermore, in terms of the Schwartz \& Davis model (1981), it indicates that South African companies are either ignoring their cultures or are managing around these cultures. Given these findings, there is some question regarding the extent to which traditional views of culture and approaches to culture management are relevant in the South African situation. For example, if underlying psychosocial factors are the basic determinants of corporate culture (Schein, 1984), is it feasible to attempt to build a single, homogeneous culture in organizations whose labour force is largely heterogeneous in terms of race, language, education levels and cultural background? This research supports the notion that the predominance of personnel managers see employee heterogeneity as a given constraint thereby avoiding complex corporate culture issues and simplifying their human resource management task. However, the benefits of this simplicity must be traded off against the improved organizational performance which usually accompanies carefully planned (and often very complex) culture management programs. It is obviously a matter for 
debate whether the decision to avoid a long-term commitment to culture management is made on the grounds of rationality or on the basis of short-term expendiency.

\section{Limitations of the research}

Understanding an organization's culture is probably best achieved by interviewing randomly selected employees in each sample company. However, the impracticality of this approach for large samples necessitates the use of an alternative methodology. The research findings suggest that the personnel manager, by virtue of his position, his job requirements and his human resources training, is the most appropriate alternative sampling unit. He should be more in touch with the organization's culture than any other single employee. To the extent that the personnel manager's perceptions of corporate culture do not accord with objective reality, respondent bias will be found in this study.

There is also some question about the adequaey of the items used to measure culture strength. As yet no widely accepted, reliable technique to measure culture strength has been developed. Finally, although this survey was conducted in two large industrial areas (Port Elizabeth/ Uitenhage and East London/King Williams Town) the sample cannot be taken as being representative of South African companies in general.

\section{Conclusion}

Very little is known about corporate culture in South African companies. The research detailed in this paper suggests that there is an association between culture strength and labour relations, company performance and the style of management adopted by an organization. Furthermore, the findings indicate the existence of cultural duality in South African companies and raise several questions regarding the applicability of traditional corporate culture theory in a South African context.

\section{References}

Barney, J.B. 1986. Organisational Culture: Can it be a Source of Sustained Competitive Advantage? Acad. Manage. Rev., vol. 11, 656-665.

Brodwin, D.R. \& Bourgeois, L.J. 1984. Five Steps to Strategic Action, Calif. Manage. Rev., vol. 26, 176-190.

Deal, T.E. \& Kennedy, A.A. 1982. Corporate Cultures, Addison Wesley, Massachusetts.

Goldsmith, W. \& Clutterbuck, D. 1984. The Winning Streak, Weidenfield \& Nicolson, London. TSG

$\checkmark$ Kanter, R.M. 1983. The Change Masters, Simon \& Schuster, New York.

King, W.R. \& Clelland, D.F. 1978. Strategic Planning and Policy, Van Nostrand Reinhold, New York.

Morse, C.W. \& Martin, A. 1983. Corporate Culture. In: The Strategic Management Handbook, Albert, K.J. (Ed), McGraw Hill, New York, Chapter 17.

Ohmae, K. 1982. The Mind of the Strategist. McGraw Hill, New York.
Ouchi, W.G. 1982. Theory Z: How American Business Can Meet the Japanese Challenge, Avon Books, New York.

Pascale, R.T. 1985. The Paradox of Corporate Culture: Reconciling Ourselves to Socialization, Calif. Manage. Rev., vol. 27, 26-41.

Peters, T.J. \& Austin, N. 1985. A Passion for Excellence. Harper and Row, New York.

Peters, T.J. \& Waterman, R.H. 1982. In Search of Excellence: Lessons from America's Best Run Companies. Harper \& Row, New York.

Pettigrew, A.M. 1979. On Studying Organisational Cultures. Admin. Sci. Quart., vol. $23,570-581$.

Pinchot, G. 1985. Intrapreneuring, Harper \& Row, New York.

Schein, E.H. 1984. Coming to a New Awareness of Organisational Culture, Sloan Manage. Rev., Winter, 3-16.

Schwartz, H. \& Davis, S.H. 1981. Matching Corporate Culture \& Business Strategy. Organis. Dyn., Summer, $30-48$.

Sullivan, J.J. 1986. Human Nature, Organisations, and Management Theory, Acad. Manage. Rev., vol. 11, 534-549.

Townsend, R. 1984. Further up the Organisation, Alfred A Knopf, New York.

Viljoen, J. 1986. Worker Participation in a South African Context. S. Afr. J. Labour Rel., vol. 10, 52-58.

Appendix 1 The culture strength of (i) management and (ii) non-management staff: Research items and measurement scale

Not true of Very true of

this company this company

1. When filling a staff vacancy external applicants

are invited only as a last resort.

Managerial staff

$\begin{array}{lllll}1 & 2 & 3 & 4 & 5\end{array}$

Non-managerial staff $\begin{array}{lllll}1 & 2 & 3 & 4 & 5\end{array}$

2. Recruitment forms identify several key traits deemed crucial to the company's success, traits are defined in concrete terms and the interviewer records specific evidence of each trait.
Managerial staff

Non-managerial staff

3. A formal effort is made to acquaint all employees (especially new recruits) with the key values/beliefs of the company - including the primary strategic value.

Managerial staff

Non-managerial staff

$\begin{array}{lllll}1 & 2 & 3 & 4 & 5\end{array}$

4. All employees see their work as being directly

linked to the success of the company.

\section{Managerial staff}

Non-managerial staff

5. Employees if asked, would give basically the same answer to the question: 'What is the most important thing this company needs to do in order to succeed in the long run?'

Managerial staff

Non-managerial staff $\begin{array}{lllll}1 & 2 & 3 & 4 & 5\end{array}$

$\begin{array}{lllll}1 & 2 & 3 & 4 & 5\end{array}$ 
Appendix 2 Corporate culture strength: Research items and measurement scale

Not true of Very true of this company this company

1. When filling a staff vacancy external applicants are invited only as a last resort.* $\begin{array}{llllll}1 & 2 & 3 & 4 & 5\end{array}$ 2. Recruitment forms identify several key traits deemed crucial to the company's succes, traits are defined in concrete terms and the interviewer records specific evidence of each trait.*

3. A formal effort is made to acquaint all employees (especially new recruits) with the key values/beliefs of the company including the primary strategic value.

4. All employees see their work as being directly linked to the success of the company.

5. Employees if asked, would give basically the same answer to the question: 'What is the most important thing this company needs to do in order to succeed in the long run?'

$\begin{array}{lllll}1 & 2 & 3 & 4 & 5\end{array}$

6. The setting of goals for employees and decisions concerning the approach to be taken to a particular job are established by the individual together with his/her superior. $\begin{array}{lllll}1 & 2 & 3 & 4 & 5\end{array}$

\section{Appendix 2 Continued}

Not true of Very true of this company this company

7. The official policy of this company is to actively encourage employees at all levels $\begin{array}{lllllll}\text { to innovate and produce new ideas. } & 1 & 2 & 3 & 4 & 5\end{array}$ 8. Management training possesses a strong behavioural component in addition to a technical component. $\begin{array}{lllll}1 & 2 & 3 & 4 & 5\end{array}$

9. Critical activities are routinized and employees have no discretion on whether such activities should be performed or the manner in which they should be performed. 10. Where possible, teamwork is encouraged in this company.

$\begin{array}{lllll}1 & 2 & 3 & 4 & 5\end{array}$

11.There is abundant opportunity for employees to become involved in company-related/organized social or recreational activities. $\begin{array}{lllll}1 & 2 & 3 & 4 & 5\end{array}$ 12.Employees are given more information than they need to know in order to perform their job effectively. $\begin{array}{lllll}1 & 2 & 3 & 4 & 5\end{array}$

* Items indicated as unreliable measures of culture strength when 